\title{
Hobbes and the Plague Doctors
}

\author{
Benedict Kingsbury
}

Kia whakatōmuri te haere whakamua

(Walk backwards into the future with eyes on our past)

Whakataukī (traditional Māori precept)

Many scholars of political power and public law contributing to this volume, alike with much of the world's population, have been driven in the $2020 \mathrm{~s}$ epidemics to turn our minds to medicine, government and justice in ways we have not turned them previously. For myself - and I suspect for numerous academics - the starkest questions usually came prefaced in my mind with 'why had I not done enough to have thought more about this before?' Power and law in these kinds of troubled times were infused with, and bound into, the great issues of virus justice and vaccine justice with which the world and every kind of society is required daily to grapple. More abstractly, many of the initial questions for me were located in the large puzzle of how to place life-essential medical-scientific knowledge and associated technologies into these politico-social spaces and their governance. My own work recently has been on physical and digital infrastructures and the workers within and around them, and on the legal and infrastructural governance of data-information-knowledge-wisdom-justice.

In nearly every society, the existential importance of the visible and nonvisible work of medical professionals as well as many other workers and caregivers on the front line in infectious disease epidemics was at the forefront in coping with COVID-19. Considerable notice and thought has long been given to this work by the people doing it, of course, and in academic terms it is also prominent in feminist and sTs traditions, as well as in rich historico-cultural studies of many kinds, including specific histories of professions. Much of the deep thought about this outside Euro-Atlantic political theory has barely been absorbed inside it. In this little note, though, I write just about asking what is said (and not said) on medics in epidemic disease times within the traditional 
(male) power-focused Euro-Classical political theory canon - Thucydides, Hobbes, Foucault and the rest.

A place to start is the well-known frontispiece etched for Thomas Hobbes' Leviathan of 1651. A nearly-empty walled city is drawn immediately under the imposing (Stuart king-like) Leviathan - the humans of all sorts, the body politic which had hitherto been the multitude, are drawn within the torso and arms of the sovereign. But the city is not quite empty of human beings. A few soldiers move purposefully about in the military quarter of the town. The only other humans in the city, standing watchfully in the lower center, are two plague doctors, readily identifiable by the long-beaked masks (in which were placed anti-miasmic herbs and spices), which had become a prominent symbol of their office in the preceding decades. ${ }^{1}$ The doctors (like the soldiers) work under the oversight of the sovereign, but they stand special and apart from the multitude, and their office is highly distinctive.

Why are the plague doctors depicted there? The expert Hobbes scholars have much insight on this which I do not, but the exegetical answer is not going to be easily reached. This is Hobbes' most notable reference to plague doctors. It is pictorial rather than textual; and not directly by his own hand, for Hobbes certainly did not draw the frontispiece although he seems to have had appreciable influence on it. In any case I take this as a stimulus to speculate in my own thoughts, without any exegetical ambition as to Hobbes'.

War and plague, whether arriving from outside or spreading internally, are the two most fundamental threats, and the responsibility of the Leviathan is to ensure security against them. The depiction of those two sets of security personnel might be nothing more than a way to convey this point. Or possibly the singularity arises from some of the professional plague doctors, like some professional soldiers, being itinerant specialists, for hire at high prices when needed, and gone again when not. A third possibility, though, is that the

1 The major work on this is Francesca Falk, 'Hobbes' Leviathan und die aus dem Blick gefallenen Schnabelmasken', (2011) 39 Leviathan 247, and the corresponding chapter in her doctoral thesis publication. The portion of the printed $165_{1}$ frontispiece showing the city, the rural area, and above these the sovereign is very clear in an image, to which colour was added by Elaine Scarry: 'Engraved title page of Hobbes's Leviathan (1651) by Abraham Bosse' (PBase) <https://pbase.com/hobbes/image/151739118> accessed 19 April 2021. An original drawing inspired by the frontispiece and with the two plague doctors strikingly evident, but with the sovereign's torso now comprised of outward- gazing faces instead of inward-turned and upward-gazing human bodies, was presented to Charles II: 'Drawing of frontispiece of Leviathan, 1651' (PBase) <pbase.com/hobbes/image/151739929> accessed 19 April 2021. An overview of Western infectious disease iconography is Christine M. Boeckl, Images of plague and pestilence: iconography and iconology (Truman State University Press, 2000). 
specialist knowledge and expertise of the plague doctor, believed not to be adequately substitutable by anything else in the sovereign's armory of deployable power, has a status and standing which is not simply subsumed into the Leviathan. In some way, the itinerant plague doctors might be emblematic of transnational knowledge circulation and located in the complex history of science-experts (and medical experts) in relation to formalized ruling power.

Thucydides' report from his personal experience as a sufferer of the Athens epidemic disease of 430 BCE - whether it was typhus, typhoid fever, Ebola, or something else is not presently known - bleakly notes the struggles of the medics on the front line: 'For at first neither were the physicians able to cure it, through ignorance of what it was, but died fastest themselves, as being the men that most approached the sick; nor any other art of man availed whatsoever.'2 This note leads into Thucydides' extensive detailing of the symptoms and the societal spread and incidence of the disease, expressly provided as a record to help later people recognize the disease if they encounter it. Thucydides says explicitly that he is not qualified to comment in the contemporary contentions about the disease's etiology. He strives to record his observations with care and precision, much as case reports are written in more modern medical science. Yet when he moves on to offer an account of the aggregate sociallegal behavior in Athens during the epidemic, he seems more to make a point than to provide a similar level of observational accuracy in his reportage. He emphasizes the prevalence of wanton human behavior and the degradation or even disintegration of law, virtue and honor. ${ }^{3}$ In the classic-realist tradition of thought, Thucydides attests that the high risks of imminent death through fatal

2 Thucydides, The History of the Peloponnesian War (Thomas Hobbes tr, Bohn 1629) para 47. An edition of Hobbes' translation of Thucydides appears in William Molesworth (ed), The English Works of Thomas Hobbes of Malmesbury; Now First Collected and Edited by Sir William Molesworth, Bart. (Bohn 1839-45) 11 vols. Vol. 8, <https://oll.libertyfund.org/titles/ 771> accessed 19 April 2021. Richard Crawley's 19th century translation put it thus: 'Neither were the physicians at first of any service, ignorant as they were of the proper way to treat it, but they died themselves the most thickly, as they visited the sick most often; nor did any human art succeed any better.' Thucydides, The History of the Peloponnesian War (Richard Crawley tr, The Internet Classics Archive, 1994-20o9) <http://classics.mit.edu/Thucydides/ pelopwar.2.second.html> accessed 19 April 2021.

3 Thucydides, The History of the Peloponnesian War (Thomas Hobbes tr, Bohn 1629) para 53. In Hobbes' English translation of Thucydides' Greek: 'Neither the fear of the gods, nor laws of men, awed any man: not the former, because they concluded it was alike to worship or not worship, from seeing that alike they all perished: nor the latter, because no man expected that lives would last till he received punishment of his crimes by judgment. But they thought, there was now over their heads some far greater judgment decreed against them; before which fell, they thought to enjoy some little part of their lives.' 
infection during virulent plague, like the risks posed by intrigue of opportunists and opponents in the civil anarchy (stasis) of Corcyra, spur people to abandon established institutions and social norms in sufficient numbers that anomie appears and even itself becomes normative, begetting antinomianism. ${ }^{4}$

Evidence to confirm or contest Thucydides' report of Athenian anomie on such a scale in 430 BCE does not yet appear to have been found. In practice in other cases, however, it does not seem that well-ordered societies collapse into nomic disintegration in the face of even the more fearsomely virulent and non-discriminating diseases; ${ }^{5}$ although fear of contagious risks posed by some group (usually the poor or a minority) is often used to call forth ferocious controls.

To take the example of Northern Italy, from the Black Death onward there was consolidated an organized administrative structure and practice for bubonic plague response in particular, measures that were also tried in England in plague outbreaks of 1631 and 1665 .

Larger towns had standing health magistracies with very strong powers to act in plague emergencies (although they had difficulties exercising these against members of religious orders or their abodes). Sealing plague-suspected houses from the outside, closing the city to ingress and egress, shutting down some industries (such as silk production which produced bad aromas and was suspected of contributing to plague miasmas), compulsory 'hospitalization' (in lazarettos or pesthouses), quarantine, and perfuming (much later transformed into disinfecting) were well established responses. Quite substantial public relief was also provided by these magistracies (usually with charitable funds) to the repressed poor, including food, changes of clothing and bedding, and provision for newly-orphaned babies. Large cadres of essential services workers were enlisted, and special quite lucrative contracts were made with plague doctors. $^{6}$ The rich were generally treated more favorably than the poor, but overall few were happy about the measures. (There do not seem to have been for the plague epidemics, many equivalents of what British politician Stanley Baldwin reportedly called many of his fellow MPs after 1918: 'hard-faced men

4 Clifford Orwin, 'Stasis and Plague: Thucydides on the Dissolution of Society' (1988) 50 Journal of Politics 831 .

5 Paul Slack, The Impact of Plague in Tudor and Stuart England (OUP 1990) 4 and passim. Foucault also acknowledged this, treating this anomie as literary rather than sociological description.

6 A detailed study of one such contract is in Carlo M Cipolla, 'A Plague Doctor' in Harry Miskimin, David Herlihy, and A.L. Udovitch (eds), The Medieval City (Yale University Press 1977) 65 . 
who looked as if they had done well out of the war.') Distilling his observations from extensive study of archives in Italy, Carlo Cipolla noted that the health ordinances were:

sources of great annoyance and severe privation and thus met with strong opposition. The segregation of entire families, the separation of kindred in the horror of pesthouses, the closing of markets and trade, the consequent rise of unemployment, the burning of furnishings and goods, the prohibition of religious assemblies, the requisitioning of monasteries for use as hospitals - all these and similar measures provoked reactions which often acquired violent tones. Life was not easy for the health officers of the time. They fought a desperate battle against a formidable and yet invisible enemy. Paradoxically, their action made them highly unpopular among the people whom they were trying to protect. ${ }^{7}$

Thomas Hobbes (who was Thucydides' first English translator) regarded the provision of capacity to deal with plague (here a general term not limited to bubonic plague) and war (civil or external) as important drivers for sovereign power - including lawmaking. The Leviathan combats the disintegration described by Thucydides, or enables an exit path in its aftermath, through consolidation of the multitude into a sovereign body politic and construction of a fearsome authority to secure and maintain order. ${ }^{8}$

The simulacrum of perfected surveillance and control in the design of repressive measures against disease in the 17th century, with everyone locked in houses and intendents moving through the streets insisting on seeing everyone at windows and recording every detail, became one of Michel Foucault's major cases of power through discipline and knowledge: 'the penetration of regulation into even the smallest details of everyday life through the mediation of the complete hierarchy that assured the capillary functioning of power; not masks that were put on and taken off, but the assignment to each individual of his "true" name, his "true" place, his "true" body, his "true" disease. The plague as a form, at once real and imaginary, of disorder had as its medical and political correlative discipline. ${ }^{9}$

7 Carlo M. Cipolla, Fighting the plague in seventeenth-century Italy (University of Wisconsin Press 1981) 5-6. (At p 10 is reproduced a printed drawing from 1661 of the waxed black robe and mask then widely known as plague doctors' attire.)

8 Cf Thomas Poole, 'Leviathan in Lockdown' (London Review of Books, 1 May 2020) <https:// lrb.co.uk/blog/2020/may/leviathan-in-lockdown> accessed 19 April 2021.

9 Michel Foucault, Discipline \& Punish: The Birth of the Prison (A. Sheridan tr, Vintage Books 1995) $195^{-228 .}$ 
In both the Hobbesian and the Foucauldian accounts, fearsome state power is a central focus, and the means of its exercise closely specified. It is not difficult to see Hobbes as a student of biopolitical power avant la lettre (as Agamben does), if the foregrounding of relations between the political-state and the medical in the Leviathan frontispiece is taken as the outward symbol of an aspect of Hobbes' thought and its later reception. But can we see something different - inspirational even - in that same image?

The state's police powers predominate in the most usual readings of the literature of salus populi and biopolitics. But the 'plague doctors' and their roles nonetheless seem to have - must have - a special character. Perhaps reflection on what this place is, or how it should be deepened and cherished, might add something for long-term planning and structures. Or at least, such reflections might differ from the escapism of the 'emergency imaginary' or of a counterbucolic re-rendering of 'As You Like It' pastoralism, the real origins of which are so readily forgotten again when the sleepwalker awakes, 'normalcy' returns, and the generations change. Science- knowledge and science-roles not worked into institutions and deliberated publicly do not get transmitted between generations and across communities, and hence tend to peter out or be displaced, as the agnatologists remind us.

A feature of medical practice is that even when to some extent co-opted into disciplinary power or made into a tactic of government through laws and bureaucracy, it still retains an aura and power of separate expertise and a degree of institutionalization. There is a capacity in a massive crisis such as a human health epidemic, for medicine and its practitioners to transcend cruder aspects of governmentality and to stand, courageously, against both the disease and misguided or delinquent governmental or transnationalized power. This potential is actualized in critical care, in legions of medical personnel and transporters and mortuary personnel, in whistleblowing, in epidemiologists speaking out fearlessly even if it is risky to do so. Transposing this professional identity into the bureaucratics of a multi-cultural inter-governmental organization such as the wHo, is a hard project and a thankless one, but worth doing and re-doing. Transposing that same professional ethos into written law such as the International Health Regulations seems to have been beyond the possible in the early 2ooos and may still be now. At many moments in the near and distant past, in places and cultures and local forms of practice all over the world, one lawyer or many have found ways to stand up and act despite or without fear, as Hobbes' Frontispiece has the plague doctors stand. The more the world seems to be that of Hobbes and Foucault writ even larger, the more the role and inspiration of the plague doctors beckons the rest of us. 